\title{
Phytochemical Screening, Antioxidant and Antimicrobial activities of Senna occidentalis (L.) leaves Extract
}

\author{
Oluwakayode Odeja', Grace Obi ${ }^{1}$, Christiana Ene Ogwuche ${ }^{1}$, Elias Emeka Elemike ${ }^{1 *}$ and Yemi Oderinlo ${ }^{2}$
}

\begin{abstract}
Background: Phytochemical screening, antimicrobial and antioxidant activities of the hexane, ethylacetate and methanol crude extracts of Senna occidentalis (L.) leaves were studied in this work. The aim of the work is to ascertain the level of antimicrobial and antioxidant properties of different solvent extracts of Senna occidentalis plant.

Methods: The preliminary screening of the various extracts was carried out using standard methods and the results revealed the presence of tannins, alkaloids, reducing sugar, phenols, anthraquinones, resins, saponins and glycosides. The antimicrobial screening was carried out using the following organisms; Staphylococcus aureus, Eshericha coli, Bacillus subtilis, Pseudomonas aeruguinosa, Salmonella typhi, Klebsiellae pneumoniae, Candida albicans, Aspergillus niger, Penicillium notatum and Rhizopus stolonifer. The free radical scavenging capacity using hydrogen peroxide was equally determined to evaluate the antioxidant activities of the extracts.
\end{abstract}

Results: The results obtained showed that Senna occidentalis (L.) leaf extracts have interesting pharmacological active compounds with great radical scavenging and antimicrobial effects and as such could be used in ethno medicine for treatment of some infections and ailments.

Conclusion: Further investigations on the chemical compositions and possible isolation of active ingredients would be carried out.

Keywords: Antioxidant; Antimicrobial; Senna occidentalis (L.); Phytochemicals; Organisms; Ethnomedicine

\section{Background}

Plants are important source of drugs; especially in traditional medicine [1]. It is a common practice in Nigeria and other parts of the world to use plant in the form of crude extracts, decoction, infusion or tincture to treat common infection and chronic conditions. According to $\mathrm{WHO}$, over $70 \%$ of the world populations rely on medicinal plants for primary health care ${ }^{2}$ and there are reports from various researchers on natural substances of plant origin which are biologically active, with desirable antimicrobial and antioxidant properties [2-4].

Despite tremendous progress in human medicines, infectious diseases caused by bacteria, fungi, viruses and parasites are still a major threat to public health. There

\footnotetext{
*Correspondence: chemphilips@yahoo.com

${ }^{1}$ Department of Chemistry, Federal University of Petroleum Resources Effurun, Effurun, Delta State, Nigeria

Full list of author information is available at the end of the article
}

impact is particularly large in developing countries due to relative unavailability of medicines and the emergence of widespread drug resistance [5].

The active principle of many drugs found in plants is phytochemicals [6]. The medicinal value of these phytochemicals is because of the presence of chemical substance that produces definite physiological action on the human body [7]. Some of the valuable ones include; alkaloids, tannins, saponins, glycosides, flavonoids, phosphorus and calcium for cell growth, replacement, and body building [7]. During the last two decades, the development of drug resistance as well as the appearance of undesirable side effects of certain antibiotics has lead to the search for new antimicrobial agents mainly among plant extracts with the goal to discover new chemical structures, which overcome the above disadvantages $[8,9]$. Current research on natural molecule and products primarily focuses on plants since they can be sourced more easily 
and be selected based on their ethno-medicinal uses [10]. Interest has also increased recently in finding natural occurring antioxidants for use in foods or medicinal materials to replace synthetic antioxidants which are being restricted due to their carcinogenicity [11]. Antioxidants have become synonymous with good health; they are a class of compounds thought to prevent certain types of chemical damage caused by an excess of free radicals, charged molecules that are generated by a variety of sources including, smoking, pesticide and fumes from exhaust. Destroying free radicals may help fight cancer, heart diseases, stroke and other immune compromising diseases [12, 13].

Senna occidentalis (L.) a small shrub about $3 \mathrm{ft}$. high belong to Leguminosae family. It is native to the tropical regions of America and naturalized in Australia, eastern Africa, southern and eastern USA [14]. Plants belonging to the family have been extensively investigated because of their rich medicinal (anti-inflammatory, anti-carcinogenic, anti-mutagenic, anti-plasmodial, anti-rheumatic and hepatoprotective) and economic uses [15-19]. Despite its great importance, Senna occidentalis plant is one of the most toxic plants of veterinary interest as regards contamination of animal rations. Its poisoning effects include ataxia, diarrhea, myoglobinuria and sternal recumbency leading to death depending on the animal. Studies have shown that histopathological tests of animals fed with the plant revealed that the heart and liver were the main organs affected with myocardial necrosis and centrolobular development [20].

It is part of our continuing effort and mandate to investigate Nigeria medicinal floras, since studies on this plant showed that the nature and amount of the phytochemicals varies according to the season, geographical location and because much work has not been done on this particular genus [21]. This paper reports on the phytoconstituents, antimicrobial and antioxidant activities of Senna occidentalis.

\section{Methods}

Plant material

Fresh leaves of Senna occidentalis (L.) were collected from botanical garden of University of Ibadan, Ibadan. Specimens were identified by Mr. Donatus Eratus and authenticated by Dr. Ayodele of the Department of Botany, University of Ibadan, Oyo State, Nigeria. The leaves were chopped into pieces using knife and then air dried under shade for 10 days and grounded into mesh size and kept in a non-absorptive nylon for subsequent use.

\section{Preparation of extracts}

Dried and milled leaf materials were extracted successively with Soxhlet extractor at temperature of $80{ }^{\circ} \mathrm{C}$. Each of the solvent; hexane, ethylacetate and methanol were allowed to remain in contact with the plant material for $12 \mathrm{~h}$; the extracts were evaporated to dryness using rotary evaporator.

\section{Phytochemical analysis}

The extracts were analyzed for the presence of alkaloids, resins, tannins, saponins, flavonoids, glycosides, phenols, anthraquinones, cardiac glycosides, steroids, phlobatannins, reducing sugars [22-25].

\section{Test for alkaloids}

$0.2 \mathrm{~g}$ of extracts was shaken with $1 \% \mathrm{HCl}$ for two minutes. The mixture was filtered and drops of Dragendorff's reagent added. Formation of a precipitate indicated the presence of alkaloids.

\section{Test for saponins}

$0.2 \mathrm{~g}$ of extracts was shaken with $5 \mathrm{ml}$ of distilled water in a test tube. Frothing which persists on warming was taken as evidence for the presence of saponins.

\section{Test for tannins}

$0.2 \mathrm{~g}$ of extracts was stirred with distilled water and filtered. Ferric chloride was added to the filtrate. A blueblack, green or blue-green precipitate was taken as an evidence for the presence of tannins.

\section{Test for steroids (Salkowski's test)}

$0.2 \mathrm{~g}$ of the extracts was dissolved in $2 \mathrm{ml}$ of chloroform. Concentrated sulphuric acid was carefully added to form a lower layer. A reddish-brown colour at the interphase indicated the deoxy sugar characteristics of cardenolides.

\section{Test for cardiac-active glycoside (keller-killani test)}

$0.2 \mathrm{~g}$ of the extracts was dissolved in $2 \mathrm{ml}$ of glacial acetic acid containing one drop of ferric chloride solution followed by the addition of $1 \mathrm{ml}$ of concentrated sulphuric acid. A brown ring at the interface confirmed the presence of cardiac glycoside.

\section{Test for reducing sugars}

$0.2 \mathrm{~g}$ of the extracts was shaken with distilled water and filtered. The filtrate was boiled with drops of Fehling's solution A and B for two minutes. An orange precipitate on boiling with the Fehling's solution indicated the presence of reducing sugars.

\section{Test for flavonoids}

A little amount of magnesium powder and few drops of concentrated hydrochloric acid were added to $3 \mathrm{ml}$ of the extracts. A red or intense red colouration indicated the presence of flavonones. 


\section{Test for resins}

$5 \mathrm{ml}$ of copper acetate solution was added to $5 \mathrm{ml}$ of the extracts. The resulting solution was shaken vigorously and allowed to separate. A green coloured solution is an evidence of the presence of resin.

\section{Test for anthraquinones}

$0.2 \mathrm{~g}$ of the extracts was shaken with $4 \mathrm{ml}$ of benzene. The mixture was filtered and $2 \mathrm{ml}$ of $10 \%$ ammonia solution was added to the filtrate. The mixture was shaken and the presence of pink, red or violet colour in the ammoniacal (Lower) phase indicated the presence of free anthraquinones.

\section{Test for phenols}

$0.2 \mathrm{~g}$ of extracts was dissolved in Ferric chloride solution. A green or dirty green precipitate indicated the presence of phenolic compound.

\section{Test for phlobatannins}

The extracts $(0.5 \mathrm{~g})$ was dissolved in distilled water and filtered. The filtrate was boiled with $2 \% \mathrm{HCl}$ solution. Red precipitate shows the presence of Phlobatannins.

\section{Test for glycosides}

The extracts was hydrolyzed with $\mathrm{HCl}$ solution and neutralized with $\mathrm{NaOH}$ solution. A few drops of Fehlings solution $\mathrm{A}$ and $\mathrm{B}$ were added. Red precipitate indicates the presence of glycosides.

\section{Scavenging of hydrogen peroxide}

The ability of the extracts to scavenge hydrogen peroxide was determined according to the method by Nabavi et al., 2008a and 2008b [26, 27]. A solution of hydrogen peroxide $(2 \mathrm{mM})$ was prepared in phosphate buffer ( $\mathrm{pH}$ 7.4). The concentration of hydrogen peroxide was determined by absorption at $285 \mathrm{~nm}$ using a UV/Vis spectrophotometer. The samples at ' $1 \mathrm{mg} / \mathrm{ml}, 0.5 \mathrm{mg} /$ $\mathrm{ml}, 0.25 \mathrm{mg} / \mathrm{ml}, 0.125 \mathrm{mg} / \mathrm{ml}$ and $0.0625 \mathrm{mg} / \mathrm{ml}^{\prime}$ were added to $\mathrm{H}_{2} \mathrm{O}_{2}$. The decrease in absorbance of $\mathrm{H}_{2} \mathrm{O}_{2}$ at $285 \mathrm{~nm}$ was measured spectrophotometrically after ten minutes (10 min) against a blank solution containing the test sample in phosphate buffer solution (PBS) without $\mathrm{H}_{2} \mathrm{O}_{2}$ and blank solution containing phosphate buffer without hydrogen peroxide (control). All the tests were performed in triplicate. The percentage of hydrogen peroxide scavenged by the extracts was calculated as follows:

$$
\left.\% \text { Scavenged }\left[\mathrm{H}_{2} \mathrm{O}_{2}\right]=\left(A_{c}-A_{s}\right) / A_{c}\right] \times 100
$$

Where $A_{c}$ is the absorbance of the control and $A_{s}$ the absorbance in the presence of the sample of extract and standard $[25,26]$. The values of $\%$ inhibition were obtained from Eq. 1. For the 50 \% Inhibitory Concentration $\left(\mathrm{IC}_{50}\right)$ evaluation of the extract, graphs showing the concentration of the test samples (hexane extract, ethyl acetate extract, methanol extract and the alpha tocopherol) versus \% Inhibition ( $\% \mathrm{H}_{2} \mathrm{O}_{2}$ reduction) were plotted.

\section{Preparation of graded concentration of the samples}

$1000 \mathrm{mg}$ of each sample was weighed and dissolved into $5 \mathrm{ml}$ of the solvent of extraction in order to obtain proper dissolution. From the $200 \mathrm{mg} / \mathrm{ml}$ solution, $2.5 \mathrm{ml}$ was taken into another sample bottle and $2.5 \mathrm{ml}$ of solvent was added to give $100 \mathrm{mg} / \mathrm{ml}$. From this, $2.5 \mathrm{ml}$ is taken into another sample bottle and $2.5 \mathrm{ml}$ of solvent was added to give $50 \mathrm{mg} / \mathrm{ml}$ solution. From the $50 \mathrm{mg} /$ ml solution, $2.5 \mathrm{ml}$ was taken into another sample bottle and $2.5 \mathrm{ml}$ of solvent added to give $25 \mathrm{mg} / \mathrm{ml}$ solution. Similar procedure was followed to obtain the $12.5 \mathrm{mg} /$ $\mathrm{ml}$ and $6.25 \mathrm{mg} / \mathrm{ml}$ concentrations, using dry filter paper dispersion method.

\section{Organisms}

Bacteria- S.a : Staphylococcus aureus, E.c : Eshericha coli, B.sab: Bacillus subtilis, Ps. a : Pseudomonas aeruguinosa, Sal. $\boldsymbol{t}$ : Salmonella typhi, Klebs : Klebsiellae pneumoniae.,

Fungi- C. $\boldsymbol{a}$ : Candida albicans, $\boldsymbol{A} . \boldsymbol{n}:$ Aspergillus niger, Pen : Penicillum notatum, Rhi. : Rhizopus stolonifer.

-ve: Negative control; Methanol for methanolic extract, ethylacetate for ethylacetate extract and hexane for hexane extract.

Table 1 Different constituents of the various extracts of Senna occidentalis leaves

\begin{tabular}{|c|c|c|c|c|c|c|c|c|c|c|c|c|}
\hline Solvent & Saponin & flavonoid & Tanin & Phlobatannin & Steroid & $\begin{array}{l}\text { Cardiac } \\
\text { Glycoside }\end{array}$ & Akaloid & $\begin{array}{l}\text { Reducing } \\
\text { sugar }\end{array}$ & Phenol & Anthraquinone & Glycosides & Resin \\
\hline HSO. & - & - & - & - & - & - & + & + & - & - & + & - \\
\hline ESO & - & - & - & - & - & - & + & - & - & + & - & + \\
\hline MSO & + & - & + & - & - & - & + & - & + & + & - & + \\
\hline
\end{tabular}

HSO : Hexane extract of Senna occidentalis

ESO : Ethylacetate extract of Senna occidentalis

MSO : Methanol extract of senna occidentalis

$+:$ Present

- : Not present 
+ve: Positive control; Gentamicin $10 \mu \mathrm{g} / \mathrm{ml}$ (bacterial) and Tiocosnazole $70 \%$ (fungi).

\section{Antimicrobial screening}

The microbes used were suspended in suitable nutrition media and was poured into a sterile petri-dish and allowed to incubate for $24 \mathrm{~h}$ at $37^{\circ} \mathrm{C}$. Suitably cut circular filter paper pieces were immersed in the antibiotic solutions of both test samples and standards. Then the pieces were placed on the nutritional microbial media all over with suitable gaps in between and incubated again.

After $24 \mathrm{~h}$ of incubation, the plates were removed and the diameter of the zone of inhibition of test and standard samples were measured in millimeters.

By comparing the areas of zone of inhibition of test extracts with standard, the concentration and potency of test samples were determined.

\section{Result and discussion}

The preliminary phytochemical screening revealed the presence of alkaloids, saponins, tannins, reducing sugar, phenols, anthraquinones, glycosides and resins in some of the extracts (hexane, ethylacetate, methanol) as shown in the Table 1. The methanol extract shows the presence of saponins, tannins, alkaloids, phenols, anthraquinones and resins. The ethyl acetate extract shows alkaloids, anthraquinones and resins while the hexane extract shows the presence of alkaloids, reducing sugar and glycosides.

The ability of the extracts to scavenge hydrogen peroxide was determined according to the method by Nabavi et al.; 2008a and 2008b. In the hydrogen peroxide scavenging radical method, the percentage inhibition of the methanolic extract was in the range of $28.29 \%-86.03 \%$. The lowest concentration $(0.0625 \mathrm{mg} / \mathrm{ml})$ showed the highest percentage inhibition value $(86.03 \%)$ as shown in Fig. 1. There is a characteristic increase in inhibition as the concentration decreases. The ethylacetate extract also showed similar trend as revealed in Table 2 and Fig. 2 $(28.31 \%$ at $1.0 \mathrm{mg} / \mathrm{ml}, 52.95 \%, 84.64 \%, 88.45 \%$ at $0.5 \mathrm{mg} / \mathrm{ml}, 0.25 \mathrm{mg} / \mathrm{ml}, 0.125 \mathrm{mg} / \mathrm{ml}$ respectively, and

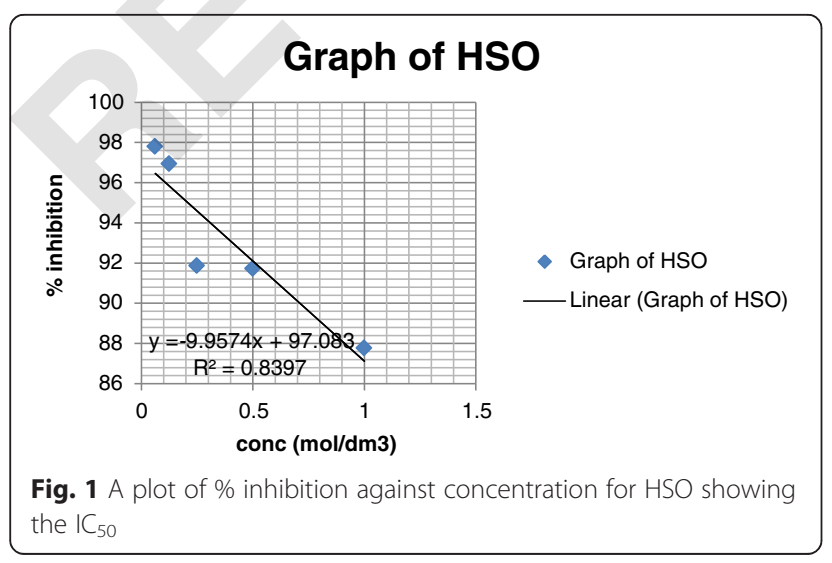

Table 2 The percentage inhibition (antioxidant levels) of the different concentrations of the three different extracts

\begin{tabular}{llllc}
\hline Conc. $\left(\mathrm{mol} / \mathrm{dm}^{3}\right)$ & HSO & ESO & MSO & a-Tocopherol \\
\hline 1.0 & 87.77 & 28.31 & 28.29 & 21.6987 \\
0.5 & 91.73 & 52.95 & 28.30 & 23.7504 \\
0.25 & 91.87 & 84.64 & 42.20 & 40.2791 \\
0.125 & 96.95 & 88.45 & 62.06 & 52.7396 \\
0.0625 & 97.80 & 93.38 & 86.03 & 75.1937 \\
\hline
\end{tabular}

$93.38 \%$ at $0.0625 \mathrm{mg} / \mathrm{ml})$. The hexane extract followed similar trend, showing $87.77 \%$ at $1 \mathrm{mg} / \mathrm{ml}$ and $91.73 \%$, $91.87 \%, 96.95 \%$ at $0.5 \mathrm{mg} / \mathrm{ml}, 0.25 \mathrm{mg} / \mathrm{ml}, 0.125 \mathrm{mg} / \mathrm{ml}$ respectively and $97.80 \%$ at $0.0625 \mathrm{mg} / \mathrm{ml}$ as shown in Fig. 3. At the lowest concentration of $0.0625 \mathrm{mg} / \mathrm{ml}$ the percentage inhibition was the highest for all the extracts. The $\mathrm{IC}_{50}$ (the concentration of the samples required to scavenge $50 \%$ of the peroxide radicals) was actually used to examine the antioxidant effectiveness of the samples. The lower the $\mathrm{IC}_{50}$, the greater the overall effectiveness of the suspected antioxidant sample in question. From the results obtained, it was revealed that the synthetic antioxidant ( $\alpha$-tocopherol), showed the best antioxidant effectiveness with $\mathrm{IC}_{50}$ of 0.24 . However, the test samples; MSO, ESO and HSO had $\mathrm{IC}_{50}$ of $0.38,0.66$ and 4.73 respectively. Therefore, the $\alpha$-tocopherol is more effective than the test samples, although they are good antioxidants. Figure 4 shows the inhibition efficiency of the $\alpha$-tocopherol which is used as standard in this study. The trend thus: $\alpha$ tocopherol $>\mathrm{MSO}>\mathrm{ESO}>\mathrm{HSO}$ (The order of decreasing antioxidant effectiveness).

The three different extracts were effective antibacterial and antifungal agents with methanol extract showing the greatest activity. The presence of phytochemicals has been attributed to be the bioactive principle responsible for the antimicrobial activities of most medicinal plants [28]. The methanol extract contains tannins, saponins, alkaloids, anthraquinones, and resins which majorly were absent in the hexane and ethyl acetate extracts. These secondary metabolites which have been reported

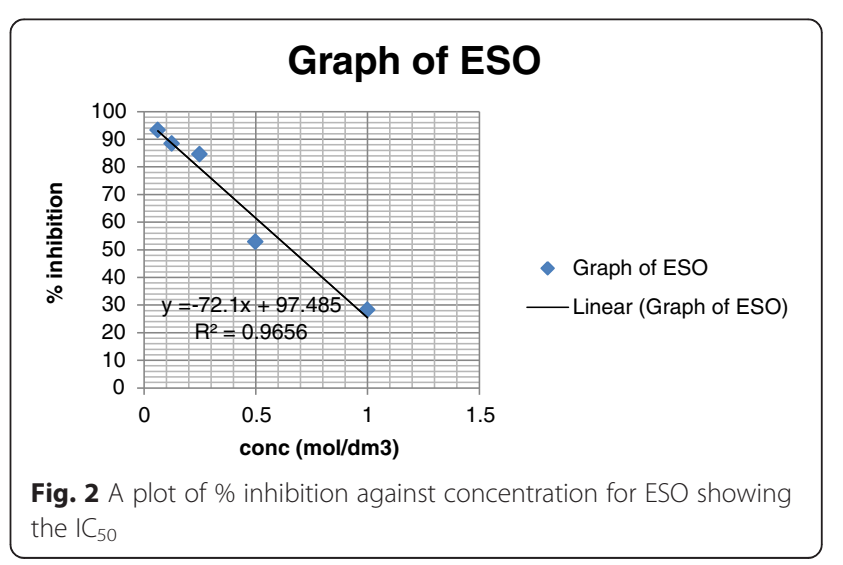




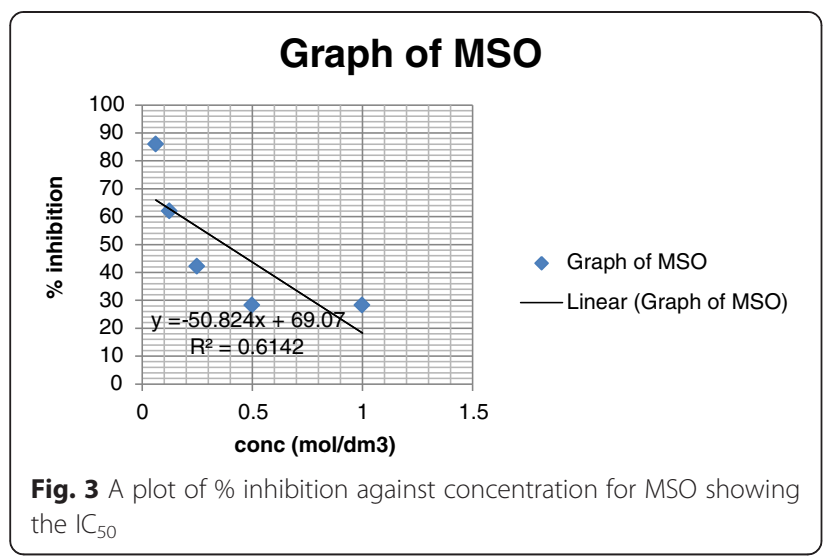

to offer great pharmacological activites both in traditional and orthodox medicine are responsible for the enhanced activity of the methanol extract as shown in Table 3.

Among all the bacterial organisms screened, the growth of Staphylococcus aureus and Eschericha coli were majorly inhibited in the methanol extract; Klebsillae pneumoniae and Staphylococuus aureus in hexane extract while Escherichia coli and Salmonella typhii in the ethylacetate extract.

Comparatively, multicellular metabolism of the Candida albicans and Aspergillus niger were the most hindered by the extracts placing them at a minimum inhibitory concentration of $25 \mathrm{mg} / \mathrm{ml}$ with few exceptions as shown in Table 3.

\section{Conclusion}

From the results obtained, this plant has the ability to scavenge for free radicals and contain bioactive compounds that can inhibit the growth of microorganisms. The methanol extract proved to be the most effective among the three extracts used and thus support the use of the plant in formulation of new antimicrobial and antioxidant drugs.

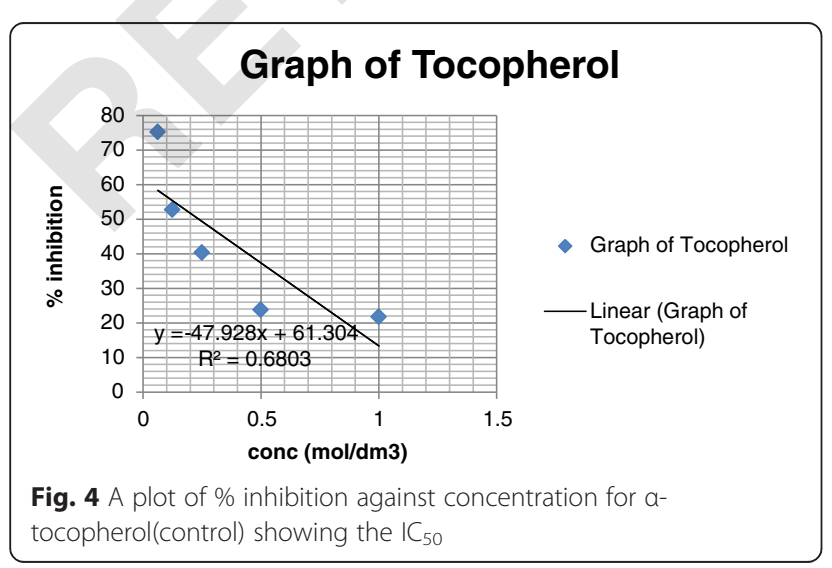

Table 3 The zones of inhibition of the isolates at different concentrations compared to the control drugs

\begin{tabular}{|c|c|c|c|c|c|c|c|c|c|c|}
\hline & & & MOS & & & & & & & \\
\hline Conc.(mg/ml) & Sa & Ec & B.Sab & Ps.a & Sal & Klebs & C.a & A.n & Rhi & Pen \\
\hline 200 & 30 & 30 & 28 & 28 & 28 & 26 & 20 & 20 & 20 & 20 \\
\hline 100 & 26 & 28 & 24 & 26 & 26 & 22 & 16 & 18 & 18 & 16 \\
\hline 50 & 22 & 24 & 20 & 22 & 22 & 18 & 14 & 14 & 14 & 14 \\
\hline 25 & 18 & 20 & 16 & 18 & 18 & 14 & 12 & 12 & 12 & 12 \\
\hline 12.5 & 14 & 16 & 12 & 14 & 14 & 12 & 10 & - & 10 & - \\
\hline 6.25 & 12 & 14 & 10 & 10 & 10 & 10 & & & & - \\
\hline & & & $\mathrm{HSO}$ & & & & & & & \\
\hline 200 & 18 & 14 & 14 & 16 & 14 & 18 & 16 & 16 & 16 & 14 \\
\hline 100 & 14 & 12 & 12 & 12 & 12 & 16 & 12 & 14 & 14 & 12 \\
\hline 50 & 12 & 10 & 10 & 10 & 10 & 14 & 10 & 12 & 12 & 10 \\
\hline 25 & 10 & & 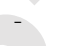 & & - & 10 & - & 10 & 10 & - \\
\hline 12.5 & & & & - & - & - & - & - & - & - \\
\hline 6.25 & & & & & - & - & - & - & - & - \\
\hline 200 & 26 & 24 & 26 & 24 & 26 & 24 & 20 & 18 & 16 & 14 \\
\hline 100 & 24 & 20 & 22 & 20 & 22 & 20 & 18 & 14 & 12 & 12 \\
\hline 50 & 18 & 16 & 18 & 16 & 18 & 16 & 12 & 12 & 10 & 10 \\
\hline 25 & 16 & 14 & 12 & 14 & 14 & 12 & 10 & 10 & - & - \\
\hline 12.5 & 12 & 10 & 10 & 10 & 10 & 10 & - & - & - & - \\
\hline 6.25 & - & - & - & - & - & - & - & - & - & - \\
\hline -ve & - & - & - & - & - & - & - & - & - & - \\
\hline$+v e$ & 38 & 38 & 40 & 38 & 38 & 38 & 28 & 28 & 26 & 28 \\
\hline
\end{tabular}

-ve : shows that the solvents used could not inhibit the growth of the microbes

$+v e$ : shows the level of inhibition of the standards used against the microbes

Further investigations on the chemical compositions and possible isolation of the active ingredient for specific functions in order to standardize the formulation for efficient medical use would be carried out.

Competing interests

The authors declare that they have no competing interests.

Authors' contributions

OO performed the laboratory analysis. OG performed part of the laboratory work and interpretation of the data. OCE was involved in the extraction and results interpretation. EEE was involved in the technicalities and made the necessary corrections in the write up. OY was involved in the antioxidant and antimicrobial analysis. All authors read and approved the final manuscript.

\section{Acknowledgments}

The authors wish to acknowledge the technologists of Department of Chemistry, Federal University of Petroleum Resources Effurun, and the management of central laboratory and Mr Charles Nwabueze of Chemistry Laboratory University of Ibadan for their assistance during the course of this research. 


\section{Author details}

${ }^{1}$ Department of Chemistry, Federal University of Petroleum Resources Effurun, Effurun, Delta State, Nigeria. ${ }^{2}$ Department of Chemical Sciences, Federal University Otuoke, Otuoke, Bayelsa State, Nigeria.

Received: 26 February 2015 Accepted: 30 June 2015

Published online: 08 September 2015

\section{References}

1. Bako SP, Bakfur MJ, John I, Bala El. Ethnomedicinal and phytochemical profile of some savanna plant species in Nigeria. Int J Bot. 2005;1(2):147-50.

2. World Health Organization, 2008. Traditional Medicine. Media Centre Fact Sheet No 134. Accessed from http://www.who.int/mediacentre/ factsheets/fs134/en/.

3. Mahesh B, Satish S. Antimicrobial activity of some important medicinal plant against plant and human pathogens. World J Agri Sci. 2008;4(S):839-43.

4. Hamid AA, Aiyelaagbe OO, Usman LA, Ameen OM, Lawal A. Antioxidants: Its medicinal and pharmacological applications. African J of Pure and Applied Chemistry. 2010;4(1):007-10.

5. Zampini IC, Cuello S, Alberto MR, Ordonez RM, Almeida RD, Solorzano E, et al. Antimicrobial activity of selected plant species from the Argentine puna against sensitive and multiresistant bacteria. J Ethnopharmacol. 2009;124:499-505.

6. El-olemy, M.M, Al-Muhtadi, F.J and Afifi, A.A (1994). Experimental phytochemistry; A laboratory Manual king saud University press pp. 350-359.

7. Harbone JB. phytochemical methods. A guide to modern technique of plant Analysis. London: Chapinan and Hall; 1973. p. 33-185.

8. Okemo PO, Bais HP, Vivanco JM. In vitro activities of Maesa lanceolata extracts against fungal plant pathogens. Fitoterapia. 2003;74:312-6.

9. Bouamama H, Noel T, Villard J, Benharref A, Jana M. Antimicrobial activities of the leaf extract of two Moroccan Cistus L species. J Ethnopharmacol. 2006:104:104-7.

10. Arora DS, Kaur GJ. Antibacterial activity of some Indian medicinal plants. J Nat Med. 2007:61:313-7.

11. Velioglu YS, Mazza G, Gao L, Oomah BD. Antioxidant activity and total phenolics in selected fruits vegetables and grain products. J Agric food chem. 1998;46:4113-7.

12. Yi-Fang C, Jie S, Xian-Hong WU, Rui-Hai L. Antioxidant and Antiproferative activities of commom vegetables. Rev J Agric Food Chem. 2002;50:6910-6.

13. Arouma OI. Methodological considerations for characterizing potential antioxidant actions of bioactive components in food plants. Mut Res. 2003;523:9-20.

14. Isah T, Mujib A. In vitro plant regeneration of coffee senna (Sennaoccidentalis) from hypocotyl-derived callus. ActaBiologicaCracoviensia. 2013:55(2):120-5.

15. Sharma N, Trikha P, Athar M, Raisuddin S. In vitro inhibition of carcinogen-induced mutagenicity by Cassia occidentalisand Emblicaofficinalis. Drug Chem Toxicol. 2000;23:477-84.

16. Vashishtha VM, John TJ, Kumar A. Clinical and pathological features of acute toxicity due to Cassia occidentalisin vertebrates. Indian J Med Res. 2009;130:23-30.

17. Yadav JP, Arya V, Yadav S, Panghal M, Kumar S, Dhankhar S. Cassia occidentalis: A review on its ethnobotany, phytochemical and pharmacological process. Fitoterapia. 2009;81:223-30.

18. Tona L, Mesia K, Ngimbi NP, Chrimwami B, Okond'ahoka CK, de Bruyne T, et al. In vivo antimalarial activity of Cassia occidentalis, Morindamorindoides and Phyllanthusniruri. Ann Trop Med Parasitol. 2001;95:47-57.

19. Kayina A, Reddy GSN. Effect of organic manures, biofertilizers and inorganic fertilizers on growth and yield of senna (Cassia angustifoliavahl.). Life Sciences leaflets. 2012;6:35-41. doi:http://lifesciencesleaflets.ning.com/.

20. Tasaka AC, Weg R, Calore EE, Sinhorini IL, Dagli MLZ, Haragudri M, et al. Toxicity testing of senna occidentalis seed in rabbits. Vet Res Comm. 2000;24:573-82.

21. Yadav JP, Arya V, Yadav S, Panghal M, Kumar S, Dhankhar S. Cassia occidentalis: A review on its ethnobotany, phytochemical and pharmacological process. Fitoterapia. 2009. doi:10.1016/j.fitote.2009.09.008.

22. Sofowara A. Medicinal plants and Traditional medicine in Africa. Ibadan, Nigeria: Spectrum Book LTD; 1993. p. 289.

23. Herborne JB. Phytochemical methods. 3rd ed. London: Chapman and Hall Ltd; 1973. p. 135-203.
24. Okwu DE. Evaluation of the chemical composition of indigenous species and flouvoring agents. Global J Pure Appl sci. 2001;7(3):455-9.

25. Rahilla TN, Rukh S, Ziaidi AA. Phytochemical screening of medicinal plants belonging to Euphorbiaceae Pak. Vet J. 1994;14(1994):160-2.

26. Nabavi SM, Ebrahimzadeh MA Abavi SF, Hamidinia A, Bekhradnia AR Determination of antioxidant activity, phenol and flavonoids content on parrotiapersicamey. Pharmacol online. 2008;2:560-7.

27. Nabavi SM, Ebrahimzadeh MA, Nabavi SF, Jafari M. Free radical scavenging activity and antioxidant capacity of Eryngium cancasicumTrantv and Froripia subpinnata. Pharmacol online. 2008;3:19-25.

28. Shimbe RY, Tor-Anyiin TA. phytochemical and antibacterial studies of hymenocardia acida roots. J Chem Soc Nigeria. 2014;39(2):119-22.

\section{Submit your manuscript to a SpringerOpen ${ }^{\odot}$ journal and benefit from:}

- Convenient online submission

- Rigorous peer review

- Immediate publication on acceptance

- Open access: articles freely available online

- High visibility within the field

- Retaining the copyright to your article

Submit your next manuscript at $>$ springeropen.com 